\title{
Contribution of the authors:
}

Ewald F. Zeer - statement and discussion of a problem; checking the logic of the statement content; correcting and editing the text; discussion of the results and conclusions.

Ekaterina Yu. Zhurlova - selection and organization of materials on the basis of the analysis of the sources and results; planning of the article; writing and text design; formulation of conclusions; listing of the used sources.

\section{ПРОФЕССИОНАЛЬНО-ПЕДАГОГИЧЕСКОЕ ОБРАЗОВАНИЕ В РОССИИ: ИСТОРИКО-ЛОГИЧЕСКАЯ ПЕРИОДИЗАЦИЯ}

\author{
В. А. Федоров ${ }^{1}$, Н. В. Третьякова ${ }^{2}$
}

Российский государственный профессионально-педагогический университет, Екатеринбург (Россия).

${ }^{1}$ E-mail:fedorov1950@gmail.com; ${ }^{2} E$-mail: tretjakovnat@mail.ru

Аннотаиия. Введение. Стремительные социально-экономические изменения требуют новых методов и форм профессиональной подготовки, перестройки содержания профессионального образования - т. е. его модернизации, которая не может осуществляться без наличия квалифицированных педагогических кадров. Поэтому качественная профессионально-педагогическая подготовка становится сегодня не просто одной из составмяющих сферы образования, а, без преувеличения, гарантией социально-экономического благополучия страны. Чтобы обеспечить должное функционирование системы профессионально-педагогического образования (ППО), необходимо понять его специфику и закономерности развития, для чего следует проследить становление и эволюцию системы.

Цель статьи - ретроспективный анализ на организационно-содержательном уровне процесса развития ППО в России как социально-педагогической системы.

Методология и методики исследования. Ведущим в исследовании проблем ППО стал историко-логический подход, позволяющий выстроить четкую последовательность формирования сложившейся к настоящему времени системы подготовки преподавателей специальных дисциплин и мастеров производственного обучения и на этой основе выявить ее недостатки и возможности.

Результаты и научная новизна. Дан краткий экскурс в историю отечественного и зарубежного профессионально-педагогического образования, существовавшего до начала XX в. Представлена хронология развития ППО в России начиная с 20-х гг. прошлого столетия до современного периода. Сог- 
масно ключевым изменениям, происходящим в целевой и организационно-содержательной части ППО, выделены и описаны шесть его этапов. Показано, что развитие данного вида образования как социально-педагогической системы обусловлено социально-экономическими факторами и административными решениями; в то же время система ППО имеет собственные закономерности, принципы функционирования и внутренний потенциал дмя дальнейшего совершенствования.

Подчеркивается актуальность обращения к истории ППО. Рефлексия по поводу накопленного положительного и отрицательного опыта способствует более точной диагностике тенденций в этой области, помогает избежать прежних ошибок, нивелировать существующие противоречия и выбрать наиболее эффективную стратегию развития ППО.

Практическая значимость. Материалы публикации могут быть востребованы научными и практическими работниками, принимающими участие в подготовке педагогов профессионального обучения и занимающимися прогнозированием и проектированием развития системы профессионально-педагогического образования.

Ключевые слова: профессионально-педагогическое образование, педагог профессионального обучения, профессиональное обучение, профессионально-педагогические кадры, этапы развития профессионально-педагогического образования в России.

для иитирования: Федоров В. А., Третьякова Н. В. профессиональнопедагогическое образование в России: историко-логическая периодизация // Образование и наука. 2017. T. 19, № 3. C. 93-119. DOI: 10.17853/1994-56392017-3-93-119.

\title{
VOCATIONAL-PEDAGOGICAL EDUCATION IN RUSSIA: HISTORICAL AND LOGICAL PERIODS
}

\author{
V. A. Fedorov ${ }^{1}$, N. V. Tretyakova ${ }^{2}$ \\ Russian State Vocational Pedagogical University, Ekaterinburg (Russia). \\ ${ }^{1}$ E-mail: fedorov1950@gmail.com; ${ }^{2 E}$-mail: tretjakovnat@mail.ru
}

Abstract. Introduction. Rapid social and economic changes demand new methods and forms of vocational training, reorganization of content of professional education, i.e. its modernizations which cannot be carried out without existence of the qualified pedagogical staff. Therefore, high-quality professional and pedagogical preparation becomes today not just one of education components, and, without exaggeration, a guarantee of social and economic wellbeing of the country. To provide due functioning of the system of vocational pedagogical educati- 
on (VPE), it is necessary to understand its specifics and regularities of development; thus, it is necessary to track formation and evolution of the system.

The aim of the study is to provide retrospective analysis at the organizational and substantial level of development of VPE in Russia as the social and pedagogical system.

Methodology and research methods. The historical and logical approach has become the leading approach while researching the problems of VPE. It allows us to build the accurate sequence of formation of the system of training of teachers of specific disciplines and masters of vocational training; on this basis to reveal its shortcomings and possibilities.

Results and scientific novelty. A brief background into history of the Russian and foreign vocational pedagogical education existing prior to the beginning of the 20th century is given. The chronology of development of VPE in Russia since 1920-s till modern period is presented. According to the key changes happening in a target and organizational-content part of VPE, six stages are distinguished and described. It is shown that development of this type of education as a social and pedagogical system is caused by socio-economic factors and administrative decisions; at the same time the VPE system has own regularities, principles of functioning and internal potential for further improvement.

The relevance of the appeal to VPE history is emphasized. The reflection concerning the accumulated positive and negative experience: promotes more exact diagnostics of tendencies in this area; helps to avoid former mistakes and to level the existing contradictions; enables to choose the most effective strategy of development of VPE.

Practical significance. The materials of the publication can be useful for scientific and practical workers who are taking part in training of teachers of vocational education and engaged in forecasting and design of development of the system of vocational pedagogical education.

Keywords: vocational pedagogical education, teacher of vocational training, vocational training, vocational teaching staff, stages of development of vocational pedagogical education in Russia.

For citation: Fedorov V. A., Tretyakova N. V. Vocational-pedagogical education in Russia: Historical and logical periods. The Education and Science Journal. 2017. Vol. 19, № 3. P. 93-119. DOI: 10.17853/1994-5639-2017-3-93-119.

\section{Введение}

Интенсивно меняющиеся социально-экономические условия, связанные с развитием рынков труда и рабочей силы, требуют изменения качества подготовки специалистов, владеющих не только специальными знаниями, но и обладающих определенными качествами, обеспечива- 
ющими их конкурентоспособность и профессиональную мобильность. В данной связи актуальной явмяется проблема модернизации современного профессионально-педагогического образования (ППО) как системы подготовки педагогов профессионального обучения.

ППО - особый вид высшего образования, значительно отличающийся от отраслевого (инженерно-технического, аграрного, экономического и т. п.) и собственно педагогического. Государственная система ППО с разной степенью успешности развивается в послереволюционной России с 1920 г. в направлениях, определяемых социально-экономическими и социально-педагогическими факторами, обусловливающими ее противоречия и недостатки [1-8].

До последнего времени среди многочисленных исследований, охватывающих содержательный и организационный аспекты становления и развития общеобразовательной школы и всех уровней профессионального образования, не были представлены работы, касающиеся развернутого описания истории ППО в России. Однако освещение этого процесса в могико-ретроспективном контексте представцяется актуальным, так как позволят определить тенденции и наметить необходимые практические шаги к обеспечению его дальнейшего развития и соответствия требованиям Аичности, общества и экономики страны.

\section{Обзор митературы}

Изучение организационно-педагогических основ подготовки педагогов профессионального обучения в США и Германии позволило установить, что с конца XIX до начала XX столетия в данных странах сложилась довольно разветвленная система такого образования. В соответствии с реализуемыми программами оно осуществлялось в различные сроки, имело разные организационные формы и разное содержание. В частности, подготовка мастеров производственного обучения и руководителей учебных мастерских в университетах и технических комледжах ряда штатов США проводимась в течение четырех мет на особых педагогических курсах (отдемениях). Учебный план предусматривал в первые два года изучение общенаучных дисциплин, а затем - преимущественно специальных предметов, непосредственно относящихся к будущей учебно-производственной деятельности: психологии (в том числе педагогической) и психолого-педагогических измерений; введения в педагогику и основ педагогики; школьной гигиены; организации образования в США; индустриального и профессионального образования; методики ручного труда и т. д. $[8$, с. 56]. Наряду с аудиторными занятиями предусматривалось прохождение еже- 
недемьной 4-часовой педагогической практики. Обучение на курсах имемо выраженную направленность на производственную подготовку [9].

Иной вариант подготовки мастеров производственного обучения осуществлялся педагогическими колмеджами на специальных курсах дневной и заочной формы обучения со сроком в один и два года соответственно. Программа была рассчитана на 480 часов и включала такие дисциплин, как история, теория и практика профессионального образования, методика труда, анализ труда и организация инструктажа, воспитание мышления и основы поведения; предусматривалось также прохождение педагогической практики $[2,8]$.

Дия учебных заведений среднего профессионального образования подготовка преподавателей специальных дисциплин осуществлялась в комледжах технического и сельскохозяйственного профиля. Использовамось две схемы. В первом случае формировались межфакультетские группы, в которые собирались студенты комледжа, желающие получить дополнительное право на ведение преподавательской деятельности; занятия в данных группах проводимись вне рамок основных образовательных программ учебного заведения; в число дисциплин психолого-педагогического блока входими основы психологии и педолого-психологические измерения, введение в педагогику и профессиональная педагогика, основы дидактики и методика сельскохозяйственных и индустриальных предметов, профессиональная консультация и управление школой $[8,9]$.

По второй схеме в структуре отраслевых комледжей организовывамись специальные индустриально- или агропедагогические отделения (факультеты). Составмение учебного плана происходияо путем изменения плана основных факультетов в сторону сокращения объема специальных (технических или сельскохозяйственных) дисциплин, введения изучения психомого-педагогических предметов и прохождения педагогической практики за счет высвободившегося времени [8, с. 57].

И по первой, и по второй схеме подготовки сроки обучения совпадали со сроками освоения основных образовательных программ комледжей и составляли 4 года. Между тем существовали и различия в организации и построении содержания подготовки преподавателей специальных дисциплин при реализации психолого-педагогического цикла. Так, в чисмо дисциплин, дополняющих ранее указанные, входими история, педагогика, педагогическая и экспериментальная психология, педология, психотехника, тестология, школьная гигиена, профессиональное образование, организация и управление школой, инспектирование школьной работы и др. $[8,9]$. 
Особенность структурно-организационной схемы профессиональнопедагогического образования в США заключалась в наличии в ней системы повышения психолого-педагогической квалификации, включавшей вечерние курсы обучения, метние ускоренные курсы, конференции и т. п. Такая система предназначалась дия инженеров и техников-практиков, которых приглашали в качестве преподавателей специальных дисциплин и руководителей производственных практик, не имевших педагогической подготовки.

Аналогичные формы подготовки преподавателей дмя системы профессионально-технического образования реализовались и в Германии.

Таким образом, проведенный нами анализ показал, что в США и Германии до 1914 г. ППО существовало как самостоятельный вид образования и его организационно-педагогические основы преимущественно совпадали.

В России вплоть до конца XIX в. целенаправленная, систематическая подготовка преподавателей дмя профессиональных учебных заведений практически отсутствовала. Согласно утвержденным в 1892 г. "Правилам для подготовмяющихся в учителя специальных предметов и руководителей практических занятий в средних и низших технических училищах" при комплектовании учебных заведений кадрами на должности преподавателей принимались кица, не имевшие профессионально-педагогического образования, но проработавшие один-два года на производстве после окончания отраслевых институтов или средних технических учимищ [8, с. 54]. То есть, выражаясь современным языком, проблема обеспечения учебных заведений педагогами профессионального обучения решамась за счет привлечения производственников. В то же время существовал небольшой опыт подготовки преподавателей специальных дисциплин дмя реальных учимищ в высших технических учебных заведениях (1873) [20]. В частности, во 2-й Военной гимназии (1865) на одно- и двухгодичных курсах обучали преподавателей и воспитателей дмя военных учебных заведений. Выпускники курсов, получившие наряду с высшим образованием неплохую педагогическую подготовку, высоко ценились как преподаватели. Аналогично готовили преподавателей дмя мореходных учебных заведений в Петербургском учимище дальнего плавания.

К началу 1900-х гг. были организованы специальные одногодичные курсы для подготовки к педагогической деятельности миц, имеющих университетское или высшее техническое образование. Однако программа этих курсов не предусматривала педагогической практики, а времени на изучение педагогики и ее истории отводимось немного. Тем не менее работу курсов 
можно охарактеризовать как первый опыт реализации аддитивной схемы "высшее техническое образование плюс педагогическая подготовка" в отечественной высшей школе [8, с. 55]. На курсы направлялись специалисты, принимаемые на профессионально-педагогические должности, но не имеющие педагогического образования. Вместе с тем вследствие острого дефицита преподавательских кадров профессиональные учебные заведения стали принимать работников без специальной педагогической подготовки и даже без университетского образования. Такая политика привела к закрытию в 1904 г. педагогических курсов [8, с. 55].

Таким образом, в России XIX - начала XX в. существовали следующие формы подготовки педагогов для системы профессионального образования:

- дополнительное 1-2-летнее обучение на базе высшего образования, реализуемое отраслевыми (техническими, агрономическими, военными и т. д.) высшими учебными заведениями. Хотя содержание такой подготовки было явно недостаточным, но идея ступенчатого (аддитивного) обучения оказалась весьма ценной;

- реализация в специализированных учебных заведениях образовательных программ, интегрирующих специальный отраслевой (технический, сельскохозяйственный, экономический и т. д.) и психолого-педагогический компоненты [8, с. 55-56].

К основным отличиям российского и зарубежного ППО рассматриваемого периода следует отнести уровень и содержание психолого-педагогической подготовки. В учебных заведениях США и Германии она имела тенденцию к фундаментальности и превосходила российский опыт по широте и разнообразию аспектов. В России отсутствовала целостная система повышения педагогической квалификации для производственников, ведущих преподавательскую работу в учебных заведениях профессионального образования и не имеющих педагогического образования [8, с. 58].

Развитие российской системы ППО отражено в работах таких отечественных исследователей, как А. Н. Веселов, И. К. Воеводин, К. А. Иванович, И. А. Каиров, Н. И. Кравцов, П. Ф. Кубрушко, В. П. Аеднев, А. Т. Маленко, П. В. Прохорович, Г. М. Романцев, В. А. Федоров и др. [3-6, 8, 10-16]. Изучение данных работ, затрагивающих отдельные аспекты ППО, показывает отсутствие подробного целенаправленного могико-исторического анализа функционирования данной системы с 20-х гг. XX в. до настоящего времени. Целостное видение истории ППО в России за период 1920-1991 гг. представлено в исследовании $\Lambda$. З. Тенчуриной [17]. Ценные сведения накоплены благодаря многолетней деятельности Учебно-методического объединения высших и сред- 
них профессиональных учебных заведений Российской Федерации по профессионально-педагогическому образованию (1988-2015 гг.). Данные материалы позволили нам выявить социальные и экономические факторы, влияющие на состояние ППО, выстроить историко-цогическую периодизацию его становмения, рассмотреть закономерности, принципы и тенденции развития в течение последнего столетия.

\section{Материамы и методы}

Методомогической основой исследования стал историко-логический подход $[18,19]$, обеспечивший целостное видение изучаемого процесса. Понимание могики исторического развития позволяет более конкретно осмыслить природу и характер исследуемого явления, в нашем случае эвомюцию системы ППО.

Дия решения исследовательских задач использовался комплекс методов: 1) теоретических: анализ научной митературы; изучение директивных, нормативных и программно-методических документов в сфере профессионального образования; системный анализ; обобщение; 2) эмпирических: изучение и обобщение педагогического опыта.

\section{Резумьтаты исследования}

В послереволюционной России система ППО от зарождения до признания ее самостоятельной отраслью развивалось сложно и долго. Структурно-организационные эмементы государственной системы ППО возникми в 1920 г. в связи с острой потребностью в преподавательских и инструкторских кадрах дмя профессионально-технических учебных заведений $[8,17,21]$. Бым создан ГАавный комитет по профессиональному образованию (ГАавпрофобр России), в обязанности которого входима организация подготовки таких кадров. Принятие данного решения на государственном уровне являлось следствием сложившейся социально-экономической ситуации: экономика страны находилась в тяжелом состоянии, хозяйственно-промышленный комплекс был разрушен во время Первой мировой (1914-1918 гг.) и Гражданской (1917-1922 гг.) войн. Задачу восстановления экономики руководство страны связывало с развитием энергетики и с переводом промышленности и сельского хозяйства на индустриальную основу. Реализация данных планов была возможна только при должном материально-техническом обеспечении и основательной кадровой поддержке производства инженерами, техниками и рабочими.

Таким образом, у государства возникла потребность в усовершенствовании системы профессионального образования. Количество профес-

Образование и наука. Том 19, № 3. 2017/ The Education and Science Journal. Vol. 19, № 3. 2017 
сиональных учебных заведений к 1921 г. по сравнению с 1910 г. увемичимось почти вдвое - с 2819 до $5272[1,8]$. Число средних и низших профессионально-технических учебных заведений (школ, учимищ, курсов, показательных мастерских и т. п.) в системе Гцавпрофобра выросло с 282 в 1919 г. до 1607 в 1921 г. По существу, в эти годы создавался прототип системы начального профессионального образования [8, с. 52].

Бурное развитие образовательной сети дмя подготовки рабочих кадров повлекло ряд социально-педагогических проблем, препятствующих ее нормальному функционированию. Основные из них - нехватка преподавателей общеобразовательных предметов; практически полное отсутствие преподавателей общетехнических, общепрофессиональных и специальных дисциплин; слабый уровень профессионально-педагогической подготовки наряду с незначительным стажем работы миц, занимавших должности преподаватеей [8, с. 52]. Положение оценивалось как близкое к катастрофе. Оперативное решение научно-педагогической, социально-педагогической и социально-экономической проблемы подготовки профессионально-педагогических кадров и насыщения ими соответствующих учебных заведений приобрело особую важность для государства. Возможный выход виделся в широком использовании в качестве педагогов профессионального обучения (преподавателей и мастеров производственного обучения) действующих технических и агрономических специалистов. Однако такое решение мишало производства части квалифицированного персонала, а значит, наносимо ущерб экономическим интересам предприятий. Поэтому на преподавательскую работу зачастую попадали не самые мучшие и опытные специалисты, что негативно сказывалось на качестве подготовки рабочих.

Кроме того, делегированные в сферу профессионального образования производственники не имели соответствующей психолого-педагогической и методической подготовки. Неудовлетворительное решение пробмемы количественного и качественного наполнения системы профессионального образования профессионально-педагогическими кадрами обусмовимо организацию их специальной подготовки.

Одним из первых структурно-организационных эмементов системы ППО стал учрежденный в составе педагогической секции ГАавпрофобра технопедагогический отдел, основными задачами которого была скорейшая разработка программы ППО и выявление его организационно-педагогических основ - структурных форм, содержания образования и технологий подготовки аграрно- и техно-педагогических кадров. Данное событие 1920 г. знаменует начало становцения государственной системы 
ППО в России. Осуществцялось оно посредством попыток снять противоречие между возрастающей потребностью в квалифицированных профессионально-педагогических кадрах, необходимых для обеспечения функционирования и развития начального и среднего профессионального образования, и практически полным их отсутствием (напомним, что в настоящее время с подобной проблемой столкнумось среднее профессиональное образование).

В России стали создаваться специальные (профессионально-педагогические) учебные заведения разного типа, выпускающие преподаватемей и мастеров производственного обучения. С целью обеспечения эффективности ППО началась разработка его организационно-педагогических основ (прежде всего структурно-организационных форм и содержания обучения), в которой учитывался опыт отечественных и зарубежных специалистов второй половины XIX - начала XX в. (до 1914 г.).

Беря за точку отсчета 1920 г., мы выделяем в истории развития российского ППО шесть этапов качественных изменений в организации и содержании образования как реакций на внешние перемены в государстве в опредеменные периоды [8, с. 58].

На первом этапе в октябре 1920 г. в связи с дефицитом преподавателей дмя профессионально-технических учебных заведений на государственном уровне были приняты решения о создании

- высших технико-педагогических учебных заведений;

- педагогических отделений при втузах и техникумах для дополнительной подготовки студентов;

- "повторительных" курсов дмя переподготовки преподавателей;

- курсов инструкторов (мастеров) по профтехническому образованию.

В 1920 г. в Петрограде открылся технико-педагогический институт - первое профессионально-педагогическое учебное заведение. На вечернюю форму обучения принимались мица с высшим специальным образованием. Учебный план, рассчитанный на 6-месячный срок, включал бомее 30 общетехнических, специальных и психолого-педагогических дисциплин. Последние занимали небольшое место в программе и были представлены экспериментальными педагогикой и психологией, историей школ и методов воспитания и обучения, четырьмя методическими дисциплинами $[8$, с. 59$]$.

Деятельность технико-педагогического института сопровождалась серьезными организационно-педагогическими трудностями: нехваткой научно-педагогических кадров, отсутствием учебно-методических разработок по ряду дисциплин, неудовцетворительной материально-техничес- 
кой базой, сложностью набора слушателей и их последующим сохранением. Обозначенные факторы порождали нарушения графика учебного процесса, что привело к закрытию института в 1922 г. как не располагающего необходимыми научными симами и достаточным оборудованием. Такой итог бым закономерен, поскольку вуз функционировал практически без научной поддержки.

Быми более удачные примеры претворения в жизнь политики подготовки педагогов профессионального обучения. Так, после расширения целевой ориентации и организационных изменений 4-месячные курсы повышения квалификации преподавателей общеобразовательных школ были переименованы в Высшие научно-педагогические курсы (ВНПК), где проходици подготовку педагоги профессионального обучения и граждане, имеющие высшее образование или заканчивающие вуз.

На техно-педагогическом отдемении ВНПК осуществляцось годичное вечернее обучение преподавателей общетехнических и специальных дисциплин дмя средних профессионально-технических учебных заведений. Образовательный процесс ориентировался преимущественно на освоение психолого-педагогических дисциплин, на которые выделялось 82\% учебного времени. Данная форма подготовки профессионально-педагогических кадров была признана в 1921 г. основной, однако разработка ее организационно-педагогических основ оставалась актуальной проблемой.

Продолжалось обсуждение основных направцений подготовки преподавателей технических и общетехнических дисциплин и мастеров производственного обучения на ВНПК и в институтах. В зависимости от базового образования предлагались различные сроки обучения: для первых двух категорий слушателей - 1 или 3 года, для мастеров - 9 месяцев [8, с. 60].

Существенным шагом вперед стало открытие в том же 1921 г. первого среднего специального педагогического учебного заведения - Московского индустриально-педагогического техникума. Здесь будущие мастера производственного обучения вместе со средним специальным образованием получали и основательную подготовку по рабочей профессии (до 6-го разряда). Это первый очень важный опыт для современной системы ППО интеграционного обучения по отраслевому, психолого-педагогическому и производственному циклам.

Прообразом современных вузов и факультетов, входящих в систему ППО России, быц Аосиноостровский агропедагогический институт (19221923 гг.). Педагогическое образование в нем задумывалось давать не как дополнительное к агрономическому, а именно как профессионально-педагогическое, объединяющее педагогическую и отраслевую подготовку. 
Ориентация на индустриализацию и комлективизацию развивающегося народного хозяйства способствовала развитию начального профессионального образования, что, в свою очередь, еще больше усугубило пробмему дефицита преподавательских кадров. Поиск путей решения проблемы способствовац созданию профессионально-педагогических институтов и факультетов в структуре педагогических вузов. Так, в начале 1930-х гг. функционировало уже 3 института специального назначения и более 10 педагогических институтов, осуществляющих подготовку педагогов дия системы начального профессионального образования. Это бым пик периода становцения системы ППО. В дальнейшем решением органов управления образованием все высшие специализированные педагогические учебные заведения будут закрыты (1937), а подготовка кадров профессионального обучения станет осуществцяться путем краткосрочных курсов (от нескольких дней до 6 месяцев).

Прерывание процесса развития системы ППО в начале 1930-х гг. связано с экономическими, политическими и социально-педагогическими факторами, такими как:

- изменение государственной образовательной политики: решения об увеличении сети и численности контингента профессиональных учебных заведений, сокращении в них сроков обучения (в вузах - до 3-4 лет), организации нескольких приемов в учебное заведение в течение года и др.;

- слабая организационная и программно-методическая база ППО (отсутствие научно обоснованных квалификационных характеристик специалистов; нестабильность организационных форм образовательных профессионально-педагогических заведений, учебных планов и программ; недостаток учебно-методической митературы и т. п.);

- недостаточное научное обеспечение системы ППО, приведшее к усилению эмпирических подходов к организации и формированию содержания подготовки педагогов профессионального обучения [8, с. 61].

Последнее обстоятельство было вызвано, во-первых, дефицитом квалифицированных научно-педагогических кадров; во-вторых, неоднозначностью и противоречивостью отношений в центральном и региональных аппаратах управления образованием к вопросу о необходимости существования ППО, следствием чего становимась недостаточная финансовая и материальная поддержка.

На протяжении всего этого сложного дмя ППО этапа деятельность учебных заведений по подготовке педагогов профессионального обучения продолжалась, как правило, от 1 года до 6 мет. За такой срок невозможно было существенно изменить ситуацию, связанную с недостатком профессионально-педагогических кадров [8, с. 62]. 
Осуществляемый же при этом поиск оптимальных организационных форм и содержания подготовки, протекающий в условиях новизны, сложности и теоретической неразработанности проблем ППО, сопровождался рядом ошибок и просчетов. Тем не менее приобретенный опыт быц, бесспорно, полезен дия последующего возрождения системы ППО.

Второй этап развития ППО приходится на 1943-1957 гг. В это время появляются индустриально-педагогические техникумы, в задачи которых входит подготовка мастеров производственного обучения, имеющих среднее техническое образование, педагогическую подготовку и высокую производственную квалификацию. Открытие техникумов было обусловлено неудовметворительной укомплектованностью учебных заведений начального профессионального образования мастерами-наставниками с педагогическим образованием. В частности, штат старших мастеров был недоукомплектован на $13,2 \%$, мастеров производственного обучения - на 20,4\%. Около 50\% мастеров и преподавателей училищ не имели образования, соответствующего занимаемой должности. Так, у более $82 \%$ мастеров производственного обучения и около 50\% старших мастеров не было даже среднего специального образования. Им обладали только соответственно $11 \%$ и 28-30\%. Доля мастеров с высшим техническим образованием колебалась в пределах 2,4-3,4\%, старших мастеров - от 14,9 до 15,2\%. Совершенно незначительную долю составляли работники, получившие педагогическое образование, - 1,1-3,3\% мастеров и 3,0-5,6\% старших мастеров [8, 17].

Частичное восстановление разрушенного в 1930-х гг. ППО благодаря заработавшим индустриально-педагогическим техникумам подтверждается тем, что в 1945 г. подготовка мастеров производственного обучения по 22 специальностям осуществлялась уже в 16 учебных заведениях. Численность учащихся в них составляла в 1946 г. 7911 человек. Контингент формировался из граждан с семилетним образованием, производственной квалификацией не ниже 3-го разряда и склонностью к педагогической работе. Содержание обучения включало циклы общеобразовательных $(39,9 \%)$, общетехнических (20,0\%), специальных $(26,2 \%)$ и педагогических $(8,6 \%)$ дисциплин, производственное обучение, педагогическую и преддипломную практики, военную подготовку и выполнение дипломного проекта. По окончании обучения выпускники техникумов были обязаны проработать по специальности в учебных заведениях не менее пяти мет [8, с. 63].

Наряду с техникумами систему ППО на этом этапе представлями педагогические отделения отраслевых институтов, которые были рекомендованы в качестве основной организационной формы подготовки преподавателей специальных и общетехнических дисциплин. 
В конце 1950-х гг. была образована структура повышения квалификации педагогических работников учебных заведений профобразования.

Третий этап развития ППО - 1958-1978 гг. Он связан с изменениями социально-педагогических условий, детерминируемых потребностями развивающейся промышиенности в рабочих, имеющих законченное среднее образование. Система начальной профессиональной подготовки на базе семилетнего общего образования осуществляла только профессиональное обучение и данную задачу не решала. Ради решения проблемы была заявлена программа реформирования системы образования, изможенная в Законе "Об укреплении связи школы с жизнью и о дальнейшем развитии системы народного образования в СССР” (24.12.1958 г.). Дия объединения общего и профессионального образования в средней школе данная программа предусматривала переход с 7-цетнего на обязательное 8-летнее обучение. При этом предполагались следующие варианты завершения среднего образования при совмещении его с производственным трудом:

- учеба в вечерней школе и работа на производстве после получения первоначальной профессиональной подготовки;

- продолжение обучения в средней образовательной трудовой политехнической школе;

- обучение на базе восьмилетней школы в техникумах.

С целью унификации все учебные заведения системы профессионально-технического образования были реорганизованы в дневные и вечерние городские и сельские профессионально-технические училища, продолжительность обучения в которых составляла от одного года до трех цет и от одного года до двух иет соответственно.

Дия обеспечения реализации в новых условиях теоретического и производственного обучения в школах и училищах была расширена подготовка мастеров и преподавателей. В 1959 г. открылись новые факультеты при педагогических и отраслевых институтах. К 1962 г. система подготовки преподавателей общетехнических и сельскохозяйственных дисциплин включала 123 вуза: 108 педагогических, 9 технических и 6 сельскохозяйственных. Благодаря этому был получен богатый опыт по формированию организационнопедагогических основ подготовки педагогов профессионального обучения с высшим образованием, который ценен и в настоящее время, так как подтверждает необходимость и возможность целенаправленного их образования на индустриально-педагогических и инженерно-педагогических факультетах в педагогических и отраслевых вузах $[8$, с. 64].

Перемены в системе ППО подтверждают закономерную обусловленность организации подготовки педагогов профессиональной школы 
с высшим образованием процессами, происходящими в системе профессионально-технического образования. В частности, к середине 1960-х гг. выросло число средних технических училищ, обучающих за 1-2 года на базе законченного среднего образования высококвалифицированных рабочих по сложным профессиям. С 1969 г. развернулась сеть средних профессионально-технических учимищ, обеспечивающих получение за 3-4 года общего среднего образования и рабочей специальности.

На третьем этапе развития ППО продолжился рост числа индустриальнопедагогических техникумов (в 1965 г. в 56 техникумах обучалось 39,9 тыс. студентов) и увеличение числа специальностей подготовки инженеров-педагогов. В 1970 г. такая подготовка велась на базе 13 вузов по специальностям 0577 - Машиностроение, 1219 - Строительство, 0315 - Электроэнергетика. Обозначенные специальности можно рассматривать в качестве аналога обсуждаемой в настоящее время идеи возможного выделения в направлениях высшего отраслевого образования "профилей", предусматривающих подготовку педагогов профессионального обучения [8, с. 65].

Распространявшаяся практика привлечения инженерно-технических работников предприятий, не имеющих психолого-педагогической подготовки, к работе в профессиональных учебных заведениях стимулировала развитие системы повышения профессионально-педагогической квалификации данной категории работников. Подтверждением тому стало создание в 1966 г. Всесоюзного института повышения квалификации инженерно-педагогических кадров с филиалами в регионах, а при отраслевых вузах с 1976 г. - факультетов повышения квалификации педагогов профессионального обучения. Однако содержание ППО в тот период нельзя назвать оптимальным: учебные планы были необоснованно перегружены и содержали дисциплины, не соответствовавшие профилю подготовки. Объясняется это руководством при их составлении ошибочным принципом: к традиционному содержанию подготовки инженера той или иной отрасли механически добавлялись дисциплины психолого-педагогического цикла. Компиляция содержания обучения специалистов в техническом вузе или педагогическом институте не учитывала специфики профессионально-педагогической деятельности. Разработка учебных планов последующих поколений осуществлялась с попытками найти более адекватное содержание образования на инженерно-педагогических факультетах и отделениях отраслевых вузов [8, с. 65-66].

В это же время общетехнические факультеты педагогических вузов решали задачу подготовки учителей труда для общеобразовательной школы, что было некой промежуточной формой обучения преподавательских кадров, существующей на стыке педагогического "школьного" образования и ППО. 
Общетехнические и индустриально-педагогические факультеты педагогических институтов и инженерно-педагогические факультеты отрасмевых вузов объединяла не только общность функций, выполняемых их выпускниками, но и близость проблем их подготовки. Большинство отраслевых вузов в отличие от педагогических учреждений не имели психомого-педагогического потенциала, а последние, в свою очередь, не были способны обеспечить высокий теоретический уровень отраслевой подготовки. А вместе они, в силу сложившихся традиций и имеющейся различной материально-технической базы, не могли осуществцять качественное обучение по рабочим профессиям, владение которыми является одной из главных особенностей деятельности специалистов профессионального обучения. Возникло также противоречие между необходимостью подготовки преподавательских кадров дмя системы начального профессионального образования, сочетающих инженерное и педагогическое мастерство с высокой рабочей квалификацией, и невозможностью обеспечить такую подготовку в существующей системе ППО [8, с. 66]. Разрешение этого противоречия многие видели в открытии специализированного вуза. K этому решению подталкивало и существовавшее в образовательной среде устойчивое мнение о необходимости подготовки мастеров производственного обучения с высшим образованием.

Четвертый этап развития ППО, начавшийся в 1979 г., был ознаменован созданием специализированного профессионально-педагогического вуза - Свердмовского инженерно-педагогического института (СИПИ, сейчас Российский государственный профессионально-педагогический университет - РГППУ) как наиболее целостной и органичной организационной формы подготовки педагогов профессионального обучения.

Открытие данного института было обусловлено, во-первых, переходом системы образования страны к всеобщему среднему образованию и превращением профтехучилищ в одну из форм получения среднего образования; во-вторых, новыми техникой и технологиями и изменениями в содержании труда рабочих в промышленности и сельском хозяйстве. Требования к профессионально-педагогическим работникам в части педагогического мастерства, уровня теоретической и практической отраслевой (инженерной) подготовки и владения рабочей специальностью стали более высокими [8, с. 67].

В системе ППО на данном этапе сочетаются размичные организационные формы вузовской подготовки, которая осуществцяется в инженерно-педагогическом институте, на инженерно-педагогических и агропедагогических факультетах и отдемениях; вводятся инженерно-педагогичес- 
кие специализации при кафедрах отраслевых вузов; создаются индустриально-педагогические и общетехнические факультеты педагогических институтов [8, с. 67]. Наряду с этим продомжает осуществляться подготовка мастеров производственного обучения в 74 индустриально-педагогических техникумах. Тем не менее уровень профессионально-педагогической квалификации кадров в учебных заведениях начального профессионального образования на начало 1987 г. оставцяет жемать мучшего: высшее образование имеют 52,9\% преподавателей и мастеров производственного обучения (включая преподавателей общеобразовательных дисциплин), среднее профессиональное образование - 38,5\%. Кадровый дефицит был обусловлен рядом причин:

- ориентацией определенной части руководителей системы образования в центральных органах управления и на местах на использование производственников в профессионально-педагогической деятельности;

- опережающими темпами роста системы начального профессионального образования по сравнению с системой ППО, масштабы которой не обеспечивали подготовку необходимого количества выпускников. С 1981 г. по 1983 г. общее количество учебных заведений в системе начального профессионального образования возросло в два раза (с 3684 до 7519), а контингент обучающихся в них увеличился в три раза (с 1064 тыс. до 3728 тыс. человек) ${ }^{1}$;

- отсутствием должной научной поддержки подготовки педагогов профессионального обучения. В одних случаях применялась схема "инженер + преподаватель", в других педагогическая подготовка шла паралмельно инженерной без интеграции их основных составцяющих;

- недостаточным количеством профицей подготовки педагогов профессионального обучения;

- невысоким качеством подготовки профессионально-педагогических работников, недостаточным дмя компетентного выполнения усложняющихся функциональных обязанностей, особенно подготовки по рабочей профессии, техническому творчеству и методике воспитательной работы [22];

- текучестью педагогических кадров и плохой их закрепляемостью в системе начального профессионального образования [8, с. 68].

Невысокие производительность и эффективность системы ППО, неразвитость ее организационной структуры привлекли внимание к состоянию и перспективам системы подготовки и повышения квалификации инженерно-педагогических кадров. Результатом такого внимания стали

1 Народное хозяйство в СССР. 1922-1982. М.: Финансы и статистика, 1982. 620 с.; Народное хозяйство в СССР. 1922-1982. М.: Финансы и статистика, 1984. 574 с.

Образование и наука. Том 19, № 3. 2017/The Education and Science Journal. Vol. 19, № 3. 2017 
следующие решения специамьного совместного заседания комегий Госкомобразования и Госпрофобра СССР (1987):

- обеспечить подготовку специалистов профессионального образования двух типов:

- с высшим образованием, способных выполнять функции преподавателя технических дисциплин и мастера производственного обучения (квалификация "инженер-педагог");

- со средним образованием, способных выполнять функции мастера производственного обучения широкого профиля (квалификация "техникмастер производственного обучения");

- обеспечить подготовку специалистов с квалификацией «инженерпедагог" в инженерно-педагогических вузах (по типу Свердловского инженерно-педагогического института) и на инженерно-педагогических факультетах втузов с планом приема 200 и более человек;

- обеспечить подготовку специалистов с квалификацией "техникмастер производственного обучения" в индустриально-педагогических техникумах;

- сократить сроки обучения в инженерно-педагогических вузах (на факультетах) для миц, имеющих среднее профессиональное образование по родственной специальности;

- ведущим вузом в области инженерно-педагогического образования утвердить Свердмовский инженерно-педагогический институт (РГППУ); создать на его базе учебно-методическое объединение по инженерно-педагогическим специальностям для разработки учебных планов и программ, другой учебно-методической документации, обобщения и распространения педагогического опыта и т. п.;

- открыть аспирантуру в вузах, ведущих подготовку инженерно-педагогических кадров с целью активизации научных исследований по проблемам инженерно-педагогического образования; ходатайствовать перед ВАК об открытии в Свердловском инженерно-педагогическом институте совета по защите диссертаций по педагогическим специальностям [8, с. 69].

Принятые решения являлись чрезвычайно важными для развития системы ППО. К началу 1990-х гг. она вкАючала уже 2 инженерно-педагогических института, 38 инженерно-педагогических факультетов вузов, 68 индустриально-педагогических техникумов и сеть институтов повышения квалификации.

Несмотря на явные достижения, потребности НПО в специалистах с профессионально-педагогическим образованием до конца не были удовлетворены. К 1990 г. высшее образование имели 89,8\% преподавателей общетехнических и специальных дисциплин; инженерно-педагогическое образова- 
ние - только 8,3\% специалистов, т. е. большинство преподавателей не получими необходимой психолого-педагогической подготовки. Аишь у каждого пятого мастера производственного обучения было высшее образование, в том числе у 3,3\% - инженерно-педагогическое. Индустриально-педагогические техникумы закончили всего 20\% мастеров. Число специалистов с высшим профессионально-педагогическим образованием в НПО выросло, но доли таких работников оставалась незначительной - около 8\% [8, с. 70].

В целом четвертый этап развития ППО характеризуется многообразием организационных форм, в том числе открытием специализированных инженерно-педагогических вузов, повышением уровня и качества теоретической, практической и производственной подготовки выпускаемых специалистов.

С 1992 г. начинается пятый этап развития ППО, во время которого шла реализация принятых на государственном уровне решений о развитии системы подготовки педагогов профессионального обучения.

Базовой площадкой дальнейшего обогащения организационно-педагогических основ ППО бым Уральский государственный профессиональнопедагогический университет (УГППУ - реорганизованный СИПИ) и созданное при нем Учебно-методическое объединение по профессиональнопедагогическому образованию. В этот период появилась новая научная специальность 13.00.08 Теория и методика профессионального образования. С целью активизации научных исследований по проблемам ППО в УГППУ открыты аспирантура, докторантура и совет по защите докторских диссертаций по педагогическим специальностям [8, с. 70].

Дия подготовки профессионально-педагогических работников с высшим образованием выделена специальность "Профессиональное обучение", с 2000 г. "Профессиональное обучение (по отраслям)". Экспериментально организована подготовка по многоуровневой системе "бакалавр - дипломированный специалист - магистр".

Инженерно-педагогическое образование трансформировалось в профессионально-педагогическое. Разработаны и реализованы государственные образовательные стандарты первого поколения, в которых предусмотрены новые квалификации педагогов профессионального обучения: агроном-педагог, модемьер-педагог, дизайнер-педагог и др., которые присваивались выпускникам до 2000 г. Дия миц, получивших высшее профессионально-педагогическое образование, с 2000 г. утверждено обобщенное наименование квалификации "педагог профессионального обучения", однозначно определяющее сферу деятельности специалиста.

НПО передано на управление в регионы. 
Шестой, современный этап развития ППО берет отсчет с 2012 г. Система ППО включает в себя профессионально-педагогический университет (РГППУ), инженерно-педагогический институт, инженерно-педагогические факультеты, профессионально-педагогические и профессиональные комледжи (техникумы), институты и факультеты повышения квалификации.

В стране происходит реорганизация системы высшего образования, утверждены федеральные государственные образовательные стандарты высшего и среднего профессионально-педагогического образования, реализуется многоуровневое ППО в системе "бакалавриат - магистратура аспирантура». Вместе с тем в системе ППО возникают проблемы, связанные, например, с выделением контрольных цифр приема отраслевым вузам по направлению "Профессиональное обучение (по отраслям)", являющемуся для них непрофильным.

Кроме утвержденного профессионального стандарта педагога профессионального обучения, появились также профессиональные стандарты подготовки специалистов среднего звена и рабочих профессий в соответствующих такой подготовке отраслях производства.

Фактически упразднена система НПО: она преобразована в начальный уровень подготовки специалиста в системе СПО. В свою очередь, СПО передано на управление в регионы, а в его системе выделен уровень подготовки по рабочим профессиям.

В образовательных организациях НПО в последние годы до ее уп-

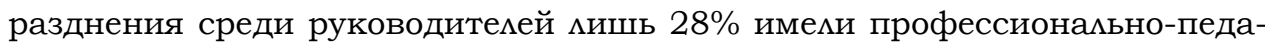
гогическое образование (26\% - высшее и $2 \%$ - среднее); среди преподавателей - 28,6\% (24\% - высшее и 4,6\% - среднее); среди мастеров производственного обучения - 24,6\% (высшее ППО - 9,7\%, среднее ППО - 14,9\%). Сейчас эта система влилась в среднее профессиональное образование и дмя оценки состояния кадрового обеспечения на уровне подготовки рабочих корректно ориентироваться на данные сведения. В целом в настоящее время в системе профессионального образования заняты педагогические работники, среди которых $28 \%$ получили ППО и $15 \%$ - высшее педагогическое образование. Следовательно, профессионально-педагогические кадры - преимущественно (около 3/5) это отраслевые специалисты (технологи, инженеры, техники и др.) - по базовому образованию не отвечают требованиям профессионального стандарта "Педагог профессионального обучения, профессионального образования и дополнительного профессионального образования", хотя у многих из них имеется значительный опыт педагогической деятельности. Вследствие этого возникла проблема приведения квалификации действующих педагогов профессионального обучения в соответствие требованиям данного профессионального стандарта. 
Сегодня все очевиднее становится противоречие между потребностями производственной сферы в высококвалифицированных рабочих и специалистах среднего звена и недостаточным числом образовательных организаций, занятых подготовкой таких кадров. С 2000 г. по 2016 г. общее число подобных учреждений сократилось в два раза (с 6596 тыс. до 3638 тыс.), контингент учащихся в них уменьшился на четверть (с 4040 тыс. до 2866 тыс. человек) ${ }^{1}$. Отчасти эти процессы носят объективный характер: снизилось число потенциальных абитуриентов - миц в возрасте 15-19 мет (с 12322 тыс. до 6829 тыс. человек) $)^{2}$, однако на очевидную динамику в сторону увеличения в ближайшее время указывают статистические данные рождаемости (с 1266800 чел. в 2000 г. до 1940579 в 2015 г.) $)^{3}$, что потребует большего количества образовательных организаций и, следовательно, большего числа педагогов профессионального обучения, т. е. развития системы ППО.

Таким образом, проведенный нами ретроспективный анализ становления и развития ППО в России позволяет отметить следующее:

1) возникновение, становление и развитие ППО обусловлено, прежде всего, потребностями профессионального образования в педагогах профессионального обучения;

2) могика развития ППО в советское время в основном подчинялась административно-командным, часто неверным решениям, и только изменение социально-экономических и социально-педагогических условий в 1992-2012 гг. позволимо ускорить процессы его развития, сделать более прогнозируемым, управцяемым и научно обоснованным;

3) профессиональное и определяющее его качество профессионально-педагогическое образование следует рассматривать сегодня как социально-педагогические детерминанты, задающие вектор и темпы социально-экономического, идейно-политического и культурно-бытового развития страны;

4) требования к педагогу профессионального обучения трансформируются в соответствии с вызовами профессионального образования и производства;

3) кАючевая дмя ППО идея интеграции отраслевой и психолого-педагогической подготовки позволяет подготовить профессионально мобильного специалиста необходимой квалификации;

1 Россия в цифрах. 2016: Краткий статистический сборник. Москва: Росстат, 2016. C. $143-144$.

2 Там же. С. 80.

3 Там же. С. 82.

Образование и наука. Том 19, № 3. 2017/ The Education and Science Journal. Vol. 19, № 3. 2017 
6) дальнейшая разработка теоретико-методомогического обоснования развития ППО связана с решением ряда исследовательских задач:

- систематизацией и обобщением опыта изысканий в области ППО;

- формированием методологической и теоретической базы ППО, основ его стандартизации;

- разработкой концепций ППО;

- изучением закономерностей развития профессионального образования и ППО;

- разработкой и проектированием содержания ППО.

Особенностью решения данных исследовательских задач является их научно-практический характер: фундаментальные проблемы рассматриваются в тесной связи с прикладными; результаты, представляемые в качестве научных идей и концепций, одновременно в той или иной мере реализуются; теоретические исследования сопровождаются инновациями и экспериментом.

Детальное изучение истории развития системы ППО способствовало созданию научной школы академика РАО Г. М. Романцева, в рамках которой происходит накопцение научного опыта в области ППО и передача его от одного покомения ученых другому [23, 24].

Каждый из социально-экономических этапов развития страны находит свое отражение в развитии системы ППО: на содержательном и институциональном уровнях она испытывает на себе происходящие в обществе изменения. В ближайшей перспективе задачами ППО явцяются:

1) реализация интегрированной подготовки специалистов в соответствии с федеральными государственными образовательными стандартами по направцению "Профессиональное обучение (по отраслям)";

2) дополнительная психолого-педагогическая подготовка выпускников отраслевых вузов или соответствующая деятельности дополнительная отраслевая подготовка миц, закончивших педагогические вузы.

Дия последующего совершенствования системы ППО необходимо принимать во внимание присущие ей особенности, закономерности и противоречия и учитывать, что в настоящее время

- основные направления развития системы ППО определяются требованиями, выдвигаемыми системой подготовки квалифицированных рабочих и специалистов среднего звена и высокотехнологичным производством;

- для современного профессионального образования нужен педагог профессионального обучения особого типа - специалист с высшим образованием, имеющий отраслевую, психолого-педагогическую и технологическую (производственную) подготовку. 


\section{Закиючение}

Развитие ППО как социально-педагогической системы обусловлено влиянием социальных, экономических факторов и административных решений, в то же время данная система функционирует на основе собственных закономерностей и принципов и имеет внутренний потенциал для дальнейшего развития.

Анализ качественных изменений в организации и содержании ППО, явцяющихся реакцией на социально-экономические условия в определенные исторические периоды, позволил выявить этапы его становления и развития. Предложенная периодизация становления и развития ППО в России может быть использована исследователями, административными и педагогическим работниками различных (федерального, регионального, объектового) уровней дмя изучения современного состояния ППО и последующего прогнозирования и проектирования его развития в стране; оценки работы образовательных организаций, реализующих направления подготовки педагогов профессионального обучения; опредемения направмений решения проблем развития ППО в динамично изменяющихся социально-экономических и социально-педагогических условиях.

Статья рекомендована к публикаиии д-ром физ.-мат. наук, профр. В. А. Гапониевьм

\section{Список использованных источников}

1. Аникст О. Рост и кризис профобразования // Вестник профессионально-технического образования. 1922. № 1-3. С. 3-4.

2. Барбашов Н. И. О подготовке педкадров в САСШ // За педагогические кадры. 1931. № 2. С. 57-60.

3. Веселов А. Н. Профессионально-техническое образование в СССР: отчет по истории среднего и низшего профтехобразования. Москва: Профтехиздат, 1961. $436 \mathrm{c}$.

4. Воеводин И. К. Профессионально-техническая подготовка кадров дАя тяжелой индустрии СССР. 1917-1972. Курск: Курский педагогический институт, 1973. 260 с.

5. Иванович К. А. Сельскохозяйственное образование в СССР. Москва: Современная наука, 1958. 240 с.

6. Каиров И. А. О подготовке кадров педагогов-специалистов для средних и низших профтехнических учебных заведений. О подготовке педагогических кадров: сборник трудов. Москва: Работник просвещения, 1930. С. 37-40.

7. Федоров В. А. Методомогические подходы к разработке организационно-педагогических основ управления развитием профессионально-педагогического образования // Образование и наука. 1999. № 1 (1), С. 52-69. 
8. Федоров В. А. Профессионально-педагогическое образование: теория, эмпирика, практика. Екатеринбург: Уральский государственный профессионально-педагогический университет, 2001. 330 с.

9. Шеварев П. А. Подготовка работников в области индустриального и сельскохозяйственного образования в США и Германии. Инженер-педагог: сборник трудов. Москва: Московское высшее техническое училище, 1928. С. 113-129.

10. Кравцов Н. И. Содержание методической работы в системе профессионально-технического образования. Москва: Высшая школа, 1977. 342 с.

11. Кубрушко П. Ф. Содержание профессионально-педагогического образования. Москва: Высшая школа, 2001. 236 с.

12. Аеднев В. П. Школа педагогических кадров на среднем Урале. Свердмовск: Свердмовский инженерно-педагогический институт, 1975. 75 с.

13. Маленко А. Т. Подготовка инженерно-педагогических кадров дмя системы профессионально-технического образования. Минск: Высшая школа, 1980. 166 c.

14. Прохорович П. В., Коваленко И. Г. Очерк развития советской профессионально-технической школы. Минск: Высшая школа, 1975. 160 с.

15. Романцев Г. М., Федоров В. А., Мокроносов А. Г. Профессиональное образование в системе обеспечения модернизируемой экономики рабочими кадрами // Университетское управление: практика и анализ. 2012. № 6 (82). C. 6-13.

16. Романцев Г. М., Федоров В. А., Осипова И. В., Тарасюк О. В. Уровневое профессионально-педагогическое образование: проблемы стандартизации. Екатеринбург: Российский государственный профессионально-педагогический университет, 2011. 544 с.

17. Тенчурина $\Lambda$. З. История профессионально-педагогического образования. Москва: Педагогика-Пресс, 1998. 304 с.

18. Гегель Г. В. Энциклопедия философских наук: в 3 т. Москва: Мысль, 1977. T. 3. $471 \mathrm{c}$.

19. Поппер К. Аогика и рост научного знания. Москва: Прогресс, 1983. $605 \mathrm{c}$.

20. Паначин Г. Ф. Педагогическое образование в России: Историко-педагогические очерки. Москва: Педагогика, 1979. 216 с.

21. Fedorov V. A., Tretyakova N. V. The Development of Vocational Pedagogical Education in Russia (Organizational and Pedagogical Aspect). International Journal of Environmental and Science Education, 2016. № 11 (17). P. 9803-9818.

22. Зеер Э. Ф. Профессиональное становление мичности инженера-педагога. Свердловск: Уральский государственный университет, 1988. 120 с.

23. Федоров В. А. Профессионально-педагогическое образование в изменяющихся социально-экономических условиях: научное обеспечение развития // Образование и наука. 2008. № 9. С. 127-135.

24. Федоров В. А., Хаматнуров Ф. Т. Научно-образовательная школа «Научные основы развития и проектирования профессионального и профессио- 
нально-педагогического образования в России" академика РАО Г. М. Романцева // Образование и наука. 2010. № 10. С. 126-139.

\section{References}

1. Anikst O. Growth and crisis of professional training. Vestnik professional'no-tekhnicheskogo obrazovaniya. [Bulletin of Professional and Technical Training]. 1922. № 1-3. P. 3-4. (In Russian)

2. Barbashov N. I. On teacher training in the United States of North America. Za pedagogicheskie kadry. [For Pedagogical Personnel]. 1931. № 2. P. 57-60. (In Russian)

3. Veselov A. N. Professional'no-tekhnicheskoe obrazovanie v SSSR: Otchet po istorii srednego i nizshego proftekhobrazovaniya. [Vocational and technical training in the USSR: a Report on the history of secondary- and tertiary-level vocation training]. Moscow: Publishing House Proftechizdat, 1961. 436 p. (In Russian)

4. Voevodin I. K. Professional'no-tekhnicheskaya podgotovka kadrov dlya tyazheloj industrii SSSR. 1917-1972. [Vocational and technical training of personnel for the USSR heavy industry. 1917-1972]. Kursk: Kurskij pedagogicheskij institute. [Kursk Pedagogical Institute]. 260 p. (In Russian)

5. Ivanovich K. A. Sel'skohozyajstvennoe obrazovanie v SSSR. [Agricultural education in the USSR]. Moscow: Publishing House Sovremennaya Nauka, 1958. 240 p. (In Russian)

6. Kairov I. A. O podgotovke kadrov pedagogov-specialistov dlya srednih i nizshih proftekhnicheskih uchebnyh zavedenij. O podgotovke pedagogicheskih kadrov. [On training teaching specialists for secondary- and tertiary-level vocational education institutions. On training teaching personnel]. Moscow: Publishing House Rabotnik prosvescheniya, 1930. P. 37-40. (In Russian)

7. Fedorov V. A. Methodological approaches to the development of organizational - pedagogical bases of management of development of vocational-pedagogical education. Obrazovanie i nauka. [The Education and Science Journal]. 1999. № 1 (1). P. 52-69. (In Russian)

8. Fedorov V. A. Professional'no-pedagogicheskoe obrazovanie: teoriya, ehmpirika, praktika. [Vocational-pedagogical education: Theory, empirics, practice]. Ekaterinburg: Ural'skij gosudarstvennyj professional'no-pedagogicheskij universitet. [Russian State Vocational Pedagogical University]. 2001. 330 p. (In Russian)

9. Shevarev P. A. Podgotovka rabotnikov v oblasti industrial'nogo i sel'skohozyajstvennogo obrazovaniya v SSHA i Germanii. Inzhener-pedagog. [Training of personnel in the sphere of industrial and agricultural education in the United States of North America. Teaching engineer]. Moscow: Moskovskoe vysshee tehnicheskoe uchilishhe. [Moscow Higher Technical School]. 1928. P. 113-129. (In Russian)

10. Kravtsov N. I. Soderzhanie metodicheskoj raboty v sisteme professional'no-tekhnicheskogo obrazovaniya. [The content of methodological support in 
the vocational and technical education system]. Moscow: Publishing House Vysshaya Shkola, 1977. 342 p. (In Russian)

11. Kubrushko P. F. Soderzhanie professionalno-pedagogicheskogo obrazovaniya. [The content of professional-pedagogical education]. Moscow: Publishing House Vysshaya shkola, 2001. 236 p. (In Russian)

12. Lednev V. P. Shkola pedagogicheskih kadrov na srednem Urale. [School of pedagogical personnel in the Middle Ural]. Sverdlovsk: Sverdlovskij inzhenernopedagogicheskij institut. [Sverdlovsk Engineering and Pedagogical Institute]. 1975. 75 p. (In Russian)

13. Malenko A. T. Podgotovka inzhenernopedagogicheskih kadrov dlya sistemy professional'no-tekhnicheskogo obrazovaniya. [Training of engineering-pedagogical personnel for the professional and technical education system]. Minsk: Publishing House Vysshaya Shkola, 1980. 166 p. (In Russian)

14. Prokhorovich P. V., Kovalenko I. G. Ocherk razvitija sovetskoj professional'no-tehnicheskoj shkoly. [Review of the Soviet professional and technical education system development]. Minsk: Publishing House Vysshaya Shkola, 1975. 160 p. (In Russian)

15. Romancev G. M., Fedorov V. A., Mokronosov A. G. Vocational education in the provision of modernized economy workers. Universitetskoe upravlenie: praktika i analiz. [University Management: Practice and Analysis]. 2012. № 6 (82). P. 613. (In Russian)

16. Romancev G. M., Fedorov V. A., Osipova I. V., Tarasyuk O. V. Urovnevoe professional'no-pedagogicheskoe obrazovanie: problemy standartizacii. [Level of vocational-pedagogical education: problems of standardization]. Ekaterinburg: Rossijskij gosudarstvennyj professional'no-pedagogicheskij universitet. [Russian State Vocational Pedagogical University]. 2011. 544 p. (In Russian)

17. Tenchurina L. Z. Istoriya professionalno-pedagogicheskogo obrazovaniya. [History of vocational-pedagogical education]. Moscow: Publishing House Pedagogika-Press, 1998. 304 p. (In Russian)

18. Hegel G. Enciklopediya filosofskih nauk: v 3 tomah. [Encyclopedia of the philosophical Sciences: in 3 volumes]. Moscow: Publishing House Mys1, 1977. V. 2. 471 p. (In Russian)

19. Popper K. Logika i rost nauchnogo znaniya. [The logic and growth of scientific knowledge]. Moscow: Publishing House Progress, 1983. 605 p. (In Russian)

20. Panachin G. F. Pedagogicheskoe obrazovanie v Rossii: Istoriko-pedagogicheskie ocherki. [Pedagogical education in Russia: Historical-pedagogical review]. Moscow: Publishing House Pedagogika, 1979. 216 p. (In Russian)

21. Fedorov V. A., Tretyakova N. V. The Development of Vocational Pedagogical Education in Russia (Organizational and Pedagogical Aspect). International Journal of Environmental and Science Education. 2016. № 11 (17). P. 9803-9818. (Translated from English)

22. Zeer E. F. Professional'noe stanovlenie lichnosti inzhenera-pedagoga [Professional development of a teaching engineer's personality]. Sverdlovsk: Ural State University, 1988. 120 p. (In Russian) 
23. Fedorov V. A. Vocational pedagogical education in a changing socio-economic conditions: scientific development. Obrazovanie i nauka. [The Education and Science Journal]. 2008. № 9. P. 127-135. (In Russian)

24. Fedorov V. A., Hamatnurov F. T. Scientifically-educational school "Scientific basis for the development and design of professional and vocational pedagogical education in Russia" academician RAO G. M. Romantsev. Obrazovanie $i$ nauka. [The Education and Science Journal]. 2010. № 10. P. 126-139. (In Russian)

Статья поступима в редакцию 11.09.2016; принята в печать 15.02.2017.

Авторы прочитали и одобрили окончательный вариант рукописи.

\section{Об авторах:}

Федоров ВАадимир Анатомьевич - доктор педагогических наук, професcop; ORCID ID: http://orcid.org/ 0000-0001-7941-7818; Scopus Author ID: 56442038600; директор Научно-образовательного центра профессионально-педагогического образования Российского государственного профессионально-педагогического университета, Екатеринбург (Россия). E-mail: fedorov1950@gmail.com

Третьякова Наталия Вцадимировна - доктор педагогических наук, доцент; ORCID ID: orcid.org/0000-0002-8820-3114, Scopus Author ID: 57144084900; директор института гуманитарного и социально-экономического образования Российского государственного профессионально-педагогического университета, Екатеринбург (Россия). E-mail: tretjakovnat@mail.ru

Received: 11.09.2016; accepted for printing: 15.02.2017.

The authors have read and approved the final manuscript.

\section{About the authors:}

Vladimir A. Fedorov - Doctor of Pedagogical Sciences, Professor; ORCID ID: http://orcid.org/ 0000-0001-7941-7818; Scopus Author ID: 56442038600; Director of Scientific-Educational Center for Vocational-Pedagogical Education; Russian State Vocational Pedagogical University, Ekaterinburg (Russia). E-mail: fedorov1950@gmail.com

Nataliya V. Tretyakova - Doctor of Pedagogical Sciences, Associate Professor; ORCID ID: orcid.org/0000-0002-8820-3114, Scopus Author ID: 57144084900; Institute of Humanitarian and Socio-Economic Education, Russian State Vocational Pedagogical University, Ekaterinburg (Russia).E-mail: tretjakovnat@mail.ru 